\title{
RELATIONSHIP AMONG ECONOMIC DEVELOPMENT, POPULATION MIGRATION AND POPULATION DEVELOPMENT IN BALI PROVINCE OF INDONESIA
}

\author{
Budhi Made Kembar Sri, Yasa I Nyoman Mahaendra, Lecturers \\ Faculty of Economics and Business, University of Udayana, Denpasar, Bali, Indonesia \\ *E-mail: kacungdobel@yahoo.com
}

\begin{abstract}
Population development is a dynamic balance between addition and reduction in population. A large population for some circles is a positive thing, but there are also those who argue that this will add to the development burden. If reviewed regionally, additional population due to natural factors (births) is also caused by in-migration. Bali Province is a highly developed tourism sector, which attracts many residents outside Bali to migrate to Bali. But will the development of the population have an impact on economic development? The objectives of this research are: (1) to determine the impact of population migration on population development and economic development in Bali Province; $(2)$ to determine the impact of population development on economic development in Bali Province; (3) to find out whether population development mediates the impact of population migration on economic development; and (4) to find out what efforts can be made to control the population in Bali Province. This study uses secondary data types or time series data. Data were obtained from the Central Bureau Statistics of Bali Province for the past five years. Data analysis method used in this research is path analysis with WarpPLS application. The results showed that: (1) population migration had a positive and significant impact on the development of the population in Bali Province; (2) population migration has a positive and significant impact on economic development in Bali Province; (3) population development has a positive and significant impact on economic development in Bali Province; and (4) efforts to control the population can be carried out by strengthening family planning programs and equitable development to prevent unbalanced population migration in each region.
\end{abstract}

\section{KEY WORDS}

Economic development, population, migration, Bali, regional policy.

Population growth is actually a dynamic balance between two forces that increase or reduce the population. Population development will be affected by the number of births, but simultaneously will be reduced by the number of deaths. In the context of spatial mobility or population migration also affects changes in population, where immigration or in-migration will increase population and emigration or out-migration will reduce the population in an area.

A large population for some circles is a positive thing because the large population can be used as the subject of development; the economy will develop if the number of its workforce is large. But on the other hand, some circles doubt whether the large population is as an asset as previously explained, but the opposite of that is that the population is a burden for development. This relates to the fulfillment of needs which are increasingly increasing along with the development of the population. This pessimistic view is supported by the Malthus theory which states that population growth according to the temporary measurement of food growth according to the arithmetical series. The conclusions from this pessimistic view are not the prosperity that is obtained, but instead poverty will be encountered when the population is not controlled properly. Actually, the problems that arise in the population sector not only in large numbers but also in the derivatives of large quantities include population distribution, population quality, adequacy in terms of consumption, population structures that are mostly young, capital and technology ownership is also still low and consequently work productivity is decreasing as well as crucial problems related to employment. 
The phenomenon in the province of Bali is slightly different from other regions in Indonesia in terms of population development, because the dimensions are regional, so that population migration causes high population growth in this region. Its net migration has positive value which means that incoming migration is more than out migration, this can be seen from population growth during the census period that has been carried out.

Table 1 - Population Growth in Bali Province, Year 1961 - 1971 Until 2000 - 2001

\begin{tabular}{|c|c|}
\hline Period of Year & Population Growth (people) \\
\hline $1961-1971$ & $2,120,322$ \\
$1971-1980$ & $2,469,930$ \\
$1980-1990$ & $2,777,811$ \\
$1990-2000$ & $3,151,162$ \\
$2000-2010$ & $3,890,757$ \\
\hline
\end{tabular}

Source: Central Bureau of Statistics of Bali Province (2018).

For more details, population growth in Bali Province can be described as follows:

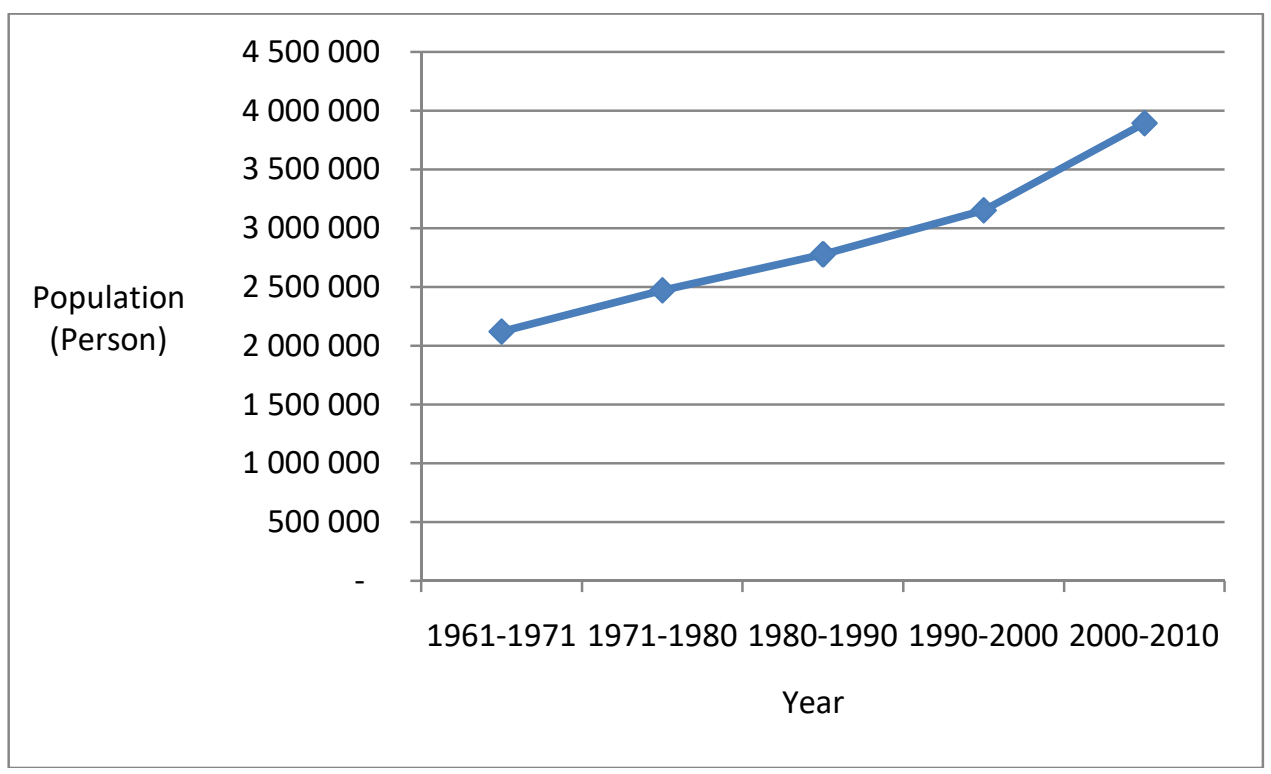

Figure 1 - Chart of Population Growth of Bali Province, Years 1961-1971 until 2000-2001 Source: Central Bureau of Statistics of Bali Province (2018)

In addition to population problems, in the economic dimension in the past, economic success indicators were always oriented towards success in generating high national income, so that the approach taken was more directed towards production activities. But in the future until now, the development orientation based on production is increasingly unpopular, because often the success of development with these indicators is not enjoyed by the population as a whole. The new paradigm of development has shifted to the importance of people centered development. Many experts say that the population is not only an object of development but also a subject of development. Because it is required that residents must participate as subjects, it is necessary to improve the quality of human resources so that the desired development can be achieved.

Population involvement in economic development becomes important in order to increase income. The policy of expanding employment opportunities is another important policy in development, because in addition to being a benchmark for the success of economic development, the next can also be used as a measure of prosperity. Rapid population growth will result in a rapid increase in the number of workers. Many empirical theories and frameworks have proven that labor is not only seen as a part of the unit in the creation of output (production), but also how the quality of the workforce interacts with other 
production factors to create added value (Wahyuningsih, 2009). Therefore, a strong effort is made to increase the participation of population income, among others by diversifying employment opportunities created by the government and the private sector. This is intended so that the population has a choice in the effort to obtain employment in an effort to generate income, so as to meet the needs needed and improve their welfare. The problem faced now is that the development of the population of the Province of Bali is still relatively high because this region has its own attraction for migrants from outside the province. But will the growth of the population have an impact on economic growth? Based on these problems this study aims to analyze the relationship between economic growth, population migration, and population development in Bali Province.

The objectives of this research are: (1) to determine the impact of population migration on population development and economic development in Bali Province; (2) to determine the impact of population development on economic development in Bali Province; (3) to find out whether population development mediates the impact of population migration on economic development; and (4) to find out what efforts can be made to control the population in Bali Province.

\section{THEORETICAL REVIEW}

Population Theory. Todaro (2005) states that migration is a process that is very selective in influencing each individual with certain economic, social, educational and demographic characteristics, so the effect on economic and non-economic factors of each individual also varies. This variation is not only found in the flow of migration between regions in the same country, but also in migration between countries. According to Mantra (2000) Migration is the movement of people from one region to another with the intention of settling in the destination. While non-permanent mobility is the movement of the population from one place to another not with the intention to settle in the destination.

Horizontal or geographical population mobility includes all population movements that cross certain boundaries in a certain period (Mantra 2000). The area limit used is the administrative boundary. Population mobility is twofold, permanent and non-permanent mobility called sercular mobility. The theories of early migration are based on surplus labor, fixed growth rates and job creation and these various theories see exit migration as a social trauma. While the new theory realizes that migration if driven by economic power is a positive and selective process.

Migration in a country can be distinguished on international migration and internal migration. Transmigration and urbanization are a form of internal migration. Internal migration is the movement of people over the administrative boundaries of the same country. The Central Bureau of Statistics (BPS) defines internal migration as a movement of population that crosses provincial boundaries. Sukamdi and Mujahid (2015) divided internal migration into four categories: migration between economic corridors, inter-provincial migration, interregional migration (regency/city/village) and rural-urban migration.

According to the Central Bureau of Statistics, internal migration can be divided into two types, namely lifetime migration and risk migration. Lifelong migration is a condition of a person's displacement that occurred long ago from a place of birth that is different from where he lives now. Risen migration is a condition of the movement of a person five years ago, which is different from the place of residence during the enumeration. Rising migration consists of incoming migration, outgoing migration and net migration. Incoming migration is a migrant entering the destination. Out migration is a migrant who comes out of the area of residence. Net migration is the difference between the amount of incoming migration minus the number of outgoing migrations.

Economic Development Theory. According to Todaro (2000) economic development means a multi-dimensional process involving major changes in social structure, social attitudes, and national institutions including acceleration or acceleration of economic growth, reduction of inequality and absolute poverty. 
Keyfit and Nitisastro (1997) explained that the ultimate goal of a country's economic development is to obtain an economic arrangement in such a way that it can guarantee the highest level of living for all citizens. The level of living in a country is usually measured by the average income of each person based on national development. Even so, increasing production results does not mean an increase in the level of livelihood, if population growth exceeds the rate of increase in production.

The Development Goal is the distribution of development and the results lead to social justice for all Indonesian people, as mandated by Pancasila. High economic growth and the creation of a healthy and dynamic national stability. Participation in development will be felt quickly by the population if employment opportunities are available well and in accordance with the conditions of the community. Job opportunities created for the population can generate income that will be used to enjoy a decent life and increase from time to time.

Economic Growth Theory. Economic growth must reflect the growth of per capita, meaning the growth of real wages and rising living standards. Thus economic growth is a condition of the development of potential GNP that reflects the growth of per capita output and the improvement of people's living standards (Murni, 2006).

According to the classical theory that output will develop in line with population development. Adam Smith, who pioneered the Classical theory, assumed that at that time land was not yet scarce, no capital had been taken into account, but only the amount of labor was taken into account. As a result, population growth is seen as a factor that can drive economic growth. Considering that output is developing in line with the development of the population, the concept of the law of diminishing return did not yet apply, as David Ricardo discovered in the following period. Because according to this theory the population is considered to be a driving force for economic growth, so the motto of many children is a lot of fortune means that more and more children, more workers can be involved to work on the land so that it adds output. The law of diminishing return is revealed after the population increases as well as national production, but after the golden age began to be felt that the longer the population increases, while the amount of land does not increase which causes the land to feel narrower. Every new worker will get smaller land to cultivate. The declining ratio between land cultivated and the large number of workers will lead to a decrease in marginal product so that it will reduce real wages.

Adam Smith (in Arsyad, 2010) reveals three main elements of a country's production system, namely: first, available natural resources, second, human resources and third, capital accumulation that must be possessed. But Smith put more emphasis on capital stock which is an element that actively determines the level of output. Economic growth is related to the increase in output per capita. There are two sides to consider, namely the total output side and the population size. Per capita output is the total output divided by the population. So the process of increasing output per capita, cannot or cannot, must be analyzed by looking at what happens with total output on the one hand, and the population on the other (Boediono, 1992).

\section{FRAMEWORK AND HYPOTHESES}

Based on the description of literature review and research objectives, the conceptual framework of this research can be described as Figure 1.

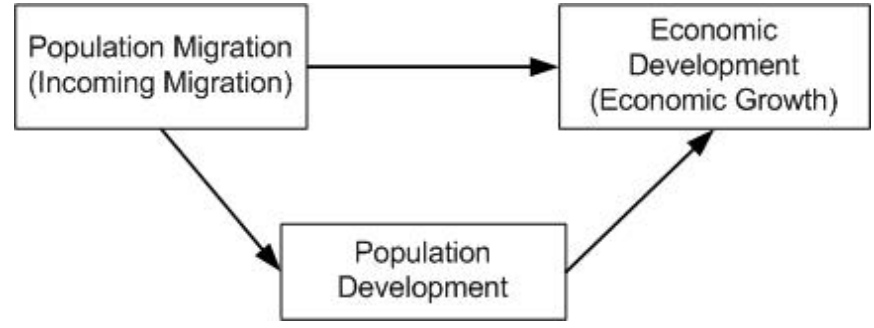

Figure 1 - Conceptual Framework 
Based on the conceptual framework, the hypotheses of this research:

- Population migration has a positive and significant effect on population development;

- Population migration has a positive and significant impact on economic development;

- Population development has a positive and significant impact on economic development;

- Population development mediates significantly the influence of population migration on economic development.

\section{METHODS OF RESEARCH}

This study uses secondary data types or time series data. Data was obtained from the Central Bureau of Statistics of Bali Province and each regency/city for the past five years. All data obtained is annual data from each regency/city in Bali Province. This time period was chosen taking into account the limitations of data sources and the limited time available. The sample in this study is the Regency/City in Bali Province.

Data analysis method used in this study is path analysis. Path analysis is used to determine the effect of a variable on other variables both direct and indirect influences.

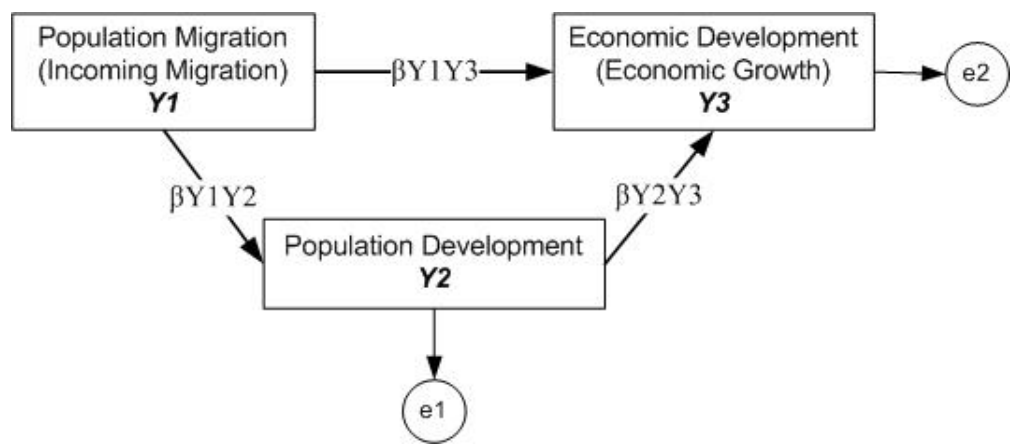

Figure 2 - Path Diagram Design

Note: Y1 = Population migration; Y2 = Population development; Y3 = Economic growth (GRDP); $\beta$ Y1Y2 = Path coefficient of population migration on population development; $\beta Y 1 Y 3=$ Path coefficient of population migration on economic growth; $\beta$ Y2Y3 = Path coefficient of population development on economic growth; $e=$ error .

Because the path coefficient has no units, it can be concluded that the greater the path coefficient, the greater the influence given by the opic le. Requirements that are needed are as follows:

- The relationship between variables is a linear relationship;

- All residual variables do not have correlation with each other;

- The pattern of relationships between variables is recursive;

- The measurement scale for both the independent variable and the dependent variable is at least the interval.

The mathematical equations for each relationship are as follows:

$$
\begin{gathered}
\mathrm{Y} 2=\beta \mathrm{Y} 1 \mathrm{Y} 2+\mathrm{e} 1 \\
\mathrm{Y} 3=\beta \mathrm{Y} 1 \mathrm{Y} 3+\beta \mathrm{Y} 2 \mathrm{Y} 3+\mathrm{e} 2
\end{gathered}
$$

\section{RESULTS AND DISCUSSION}

Population Migration in Bali Province. Migration is the movement of people from one region to another. In general, the movement carried out by the population is caused by economic factors in addition to other factors, namely social and political. Many considerations are carried out by the residents in making the move seen from the 
advantages and disadvantages. In general, Bali Province experienced an increase from the Population Census 2000 to the Population Census 2010.

For more details when compared through graphs like Figure 3, it is clear that Denpasar City is still the main destination for population migration. Whereas based on Population Census 2000 the number of migrant population in Denpasar City has reached 82,535 people, while the second most migrated destination area, namely Badung Regency, only 30,438 people.

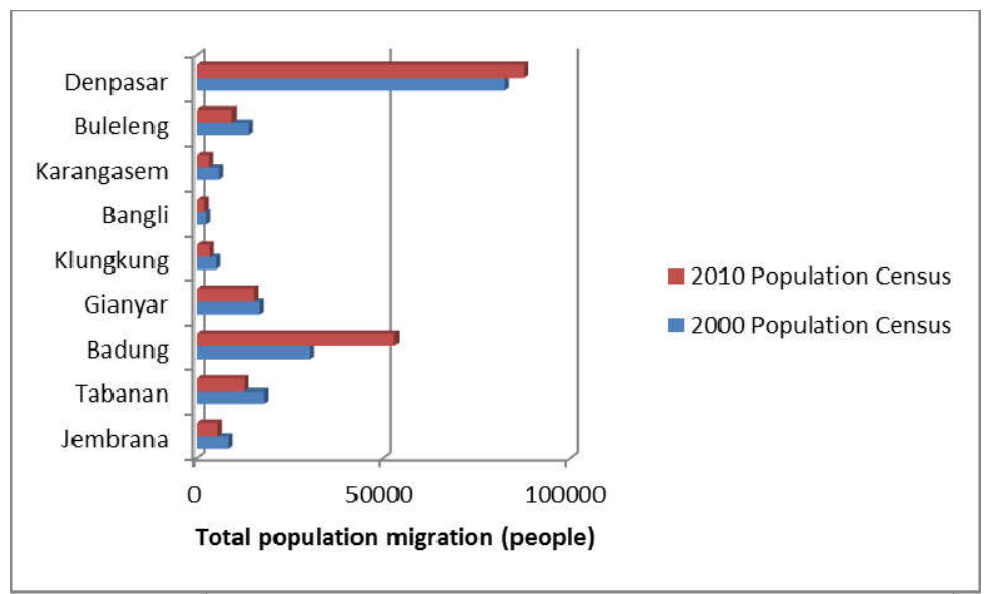

Figure 3 - Comparison of Regency/City Migration Populations in Bali Province, based on the Population Census 2000 and the Population Census 2010 Source: Central Bureau of Statistics of Bali Province (2018)

Furthermore, when viewed from the development of population migration by comparing migration in the Population Census 2000 with the Population Census 2010, it can be compared to the development of population migration as Figure 4. It is seen that the development of positive migration only occurs in two regions, namely Badung Regency and Denpasar City, but in aggregate Bali Province still experiences positive population development. Even the development of population migration in Badung Regency is very high, namely $74 \%$, while Denpasar City is only $6.07 \%$, and Bali Province is $4.46 \%$.

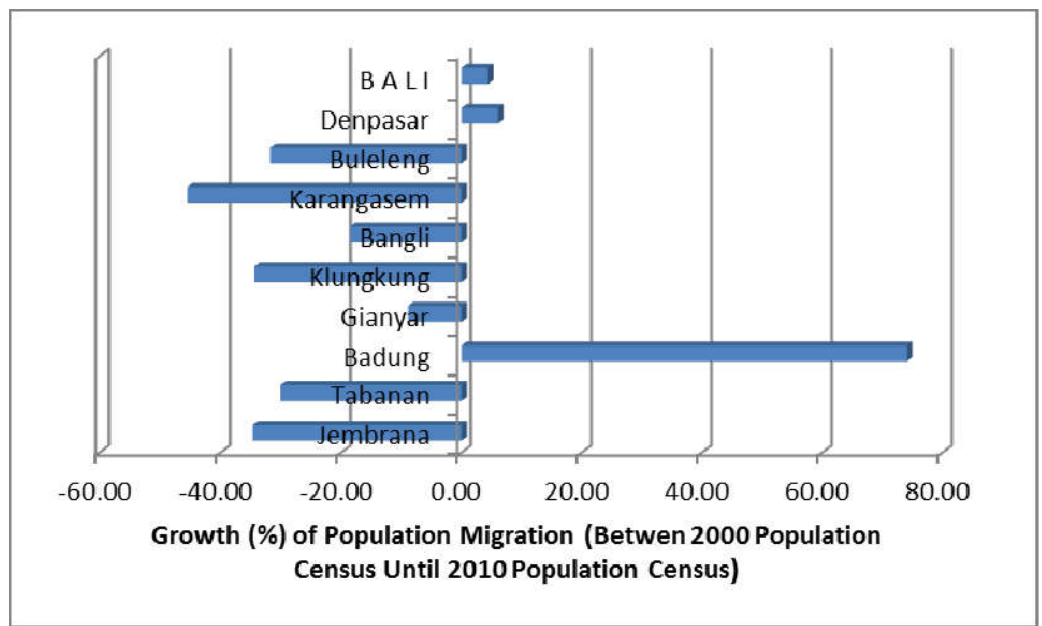

Figure 4 - Growth of Regency/City Population Migration in Bali Province, between the Population Census 2000 and the Population Census 2010 (in percent) Source: Central Bureau of Statistics of Bali Province (2018)

Badung Regency is the district with the highest economic growth compared to other regencies/cities in Bali Province. So that over the past five years, Badung Regency has become a destination for immigration, nearly $74 \%$ of the population from other 
regencies/cities and other provinces as the chosen area to settle down and find work or work.

Population Development of Bali Province. Population in Bali Province experiences a positive growth every year, even though the amount is fluctuating. Figure 5 follows graphically a comparison of the population of regencies/cities in Bali Province. Figure 5 shows that the highest population is in Badung Regency, while the least population is in Klungkung Regency.

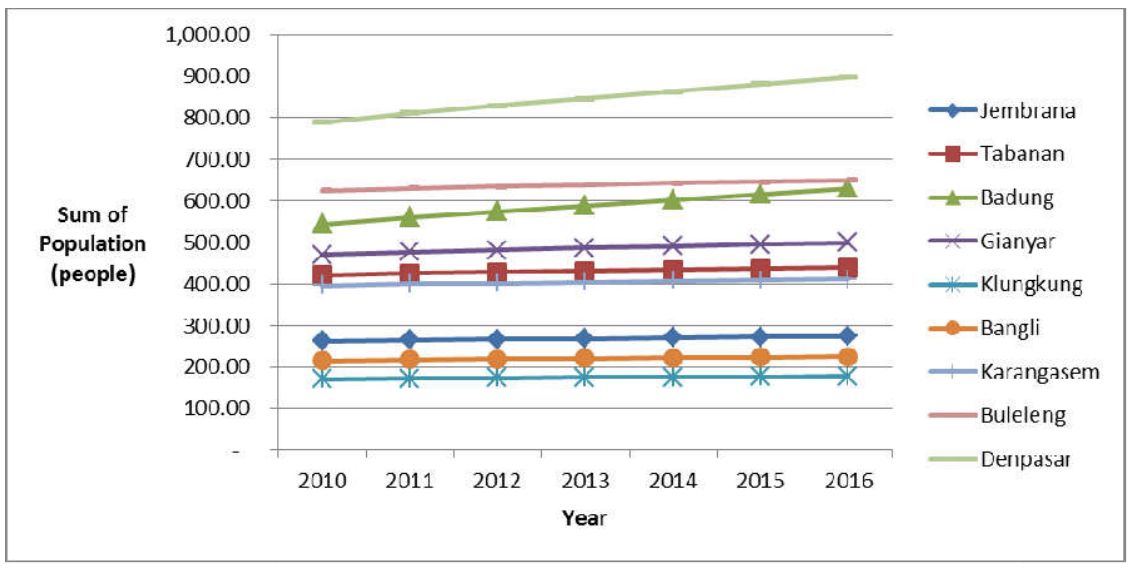

Figure 5 - Population in Bali Province in 2010 - 2016 (in thousand people) Source: Central Bureau of Statistics of Bali Province (2018)

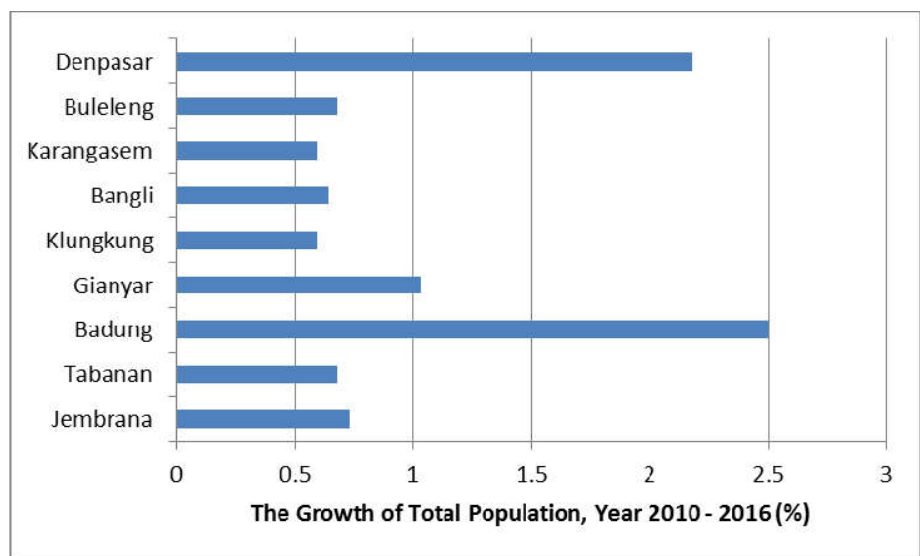

Figure 6 - Growth of Regency/City Population in Bali Province Year 2010 - 2016 (\%) Source: Central Bureau of Statistics of Bali Province (2018)

Figure 6 shows the highest population growth in Badung Regency $(2.50 \%)$, followed by Denpasar City (2.18\%), and Gianyar Regency (1.03\%).

Economic Development of Bali Province. The structure of Bali's economy in general is supported by three main sectors, namely the agricultural sector, small industry (especially the handicraft industry), and the tourism sector as the leading sector. Judging from the development of GRDP per Regency/City, Bali's GRDP is still dominated by three districts/cities, namely Badung Regency, Denpasar City, and Gianyar Regency.

The three regions are tourist destinations, such as Badung Regency which is the center of tourism accommodation, as well as the center of economic activity. Furthermore, the City of Denpasar, in addition to being the central government of the Province of Bali is also the center of economic activity, education, tourism and others. While Gianyar Regency which is a tourism destination is also an industrial center, especially small and medium-sized industries. The economic growth of the three regencies/cities is between $12.61 \%$ to $14.68 \%$. While the smallest GRDP is Bangli Regency and Klungkung Regency with an average GRDP growth of $12.15 \%$ and $12.41 \%$ per year based on current prices. Bangli Regency is 
the only regency in Bali that has no sea/beach and is not crossed by inter-provincial roads, so Bangli regency can be said to be an isolated district compared to other regencies/cities in Bali and most of the area is dry land namely forest. Bangli Regency is a water catchment area and the role of the agricultural sector is dominant compared to other sectors.

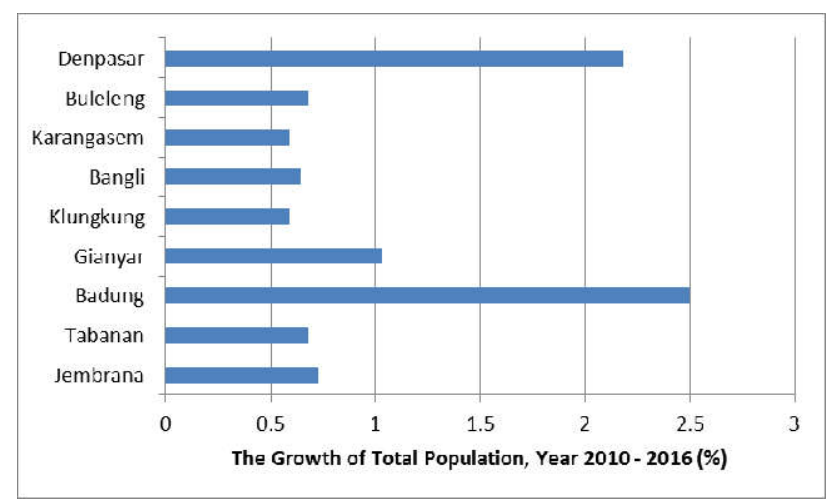

Figure 7 - Development of Regency/City Population in Bali Province, Year 2010 - 2016 (\%) Source: Central Bureau of Statistics of Bali Province (2018)

Figure 7 shows that the regency/city GRDP in general is continuously increasing from year to year. The highest increase occurred in Badung Regency, considering that Badung Regency was the center of Bali's economy. Furthermore, the difference is not too far followed by the City of Denpasar which is the center of the government of the Province of Bali. It is seen that the difference in the development of GRDP between Badung Regency and Denpasar City with other districts is quite significant.

Regression Analysis and Hypotheses Testing. As previously described on data analysis techniques, the output of the regression test results with the Warp-PLS application as in Table 1 below.

Table 1 - Result of Regression Test

\begin{tabular}{|c|c|c|c|c|}
\hline & Path Regression & $p$-values & Standard Errors & Effect Sizes \\
\hline $\mathrm{Y} 1 \rightarrow \mathrm{Y} 2$ & 0,875 & $<0,001$ & 0,093 & 0,766 \\
\hline $\mathrm{Y} 1 \rightarrow \mathrm{Y} 3$ & 0,476 & $<0,001$ & 0,107 & 0,406 \\
\hline $\mathrm{Y} 2 \rightarrow \mathrm{Y} 3$ & 0,465 & $<0,001$ & 0,107 & 0,395 \\
\hline $\mathrm{Y} 1 \rightarrow \mathrm{Y} 2 \rightarrow \mathrm{Y} 3$ & 0.407 & $<0,001$ & \\
\hline $\mathrm{R}^{2}(\mathrm{Y} 2)=0,766$ \\
$\mathrm{R}^{2}(\mathrm{Y} 3)=0,801$
\end{tabular}

Regression coefficients and p-values in Table 1 show that:

- The effect of population migration (Y1) on population development (Y2) has a regression coefficient of 0.875 and a p-value $<0.001$ so that it can be concluded that population migration (Y1) has a positive effect on population development (Y2);

- The effect of population migration (Y1) on economic development (Y3) has a regression coefficient of 0.476 and $p$-value $<0.001$ so that it can be concluded that population migration (Y1) has a positive and significant effect on economic development (Y3);

- The effect of population development (Y2) on economic development (Y3) has a regression coefficient of 0.465 and $p$-value $<0.001$ so that it can be concluded that population development (Y2) has a positive and significant effect on economic development (Y3);

- Population development (Y2) significantly mediates the effect of population migration (Y1) on economic development (Y3) with a regression coefficient of 0.407 and pvalue $<0.001$

Appropriate Table 1 It can also be seen that the $R^{2}$ value of the population development variable is 0.763 which means that 76.3 percent of the population development 
variables are influenced by population migration factors, and the remaining 23.7 percent are other factors. Furthermore, it is also known that the R2 value of the economic development variable is 0.801 , which means that as much as 80.1 percent of the economic development variables are influenced by the variables of population migration and population development, while the remaining 19.9 percent are other factors.

\section{DISCUSSION OF RESULTS}

Effect of Population Migration on Population Development in Bali Province. The results of data analysis show that population migration has a positive and significant effect on the development of the population in Bali Province. This means that if the population migration becomes more positive (in-migration) and increases, it will be followed by an increase in the population, and vice versa.

As we know, the population growth rate is dominated by demographic determinants, namely: (1) natality/fertility (birth); (2) mortality (death); (3) migration (population movement) (Suartha, 2016). Birth certainly gives an increase in population, on the contrary death will reduce the population. While migration can increase or decrease the population. If the incoming migration will increase the population, on the contrary if out migration will reduce the population.

Effect of Population Migration on Economic Development in Bali Province. Based on the results of data analysis, it is known that population migration has a positive and significant effect on the economic development of Bali Province. This means that if migration is positive (in-migration) is increasing, it will have a positive effect on the economic development of Bali, and vice versa.

As explained earlier, that the theories of early migration are based on surplus labor, a fixed rate of growth and the creation of employment and these various theories see exit migration as a social trauma. While the new theory realizes that migration if driven by economic power is a positive and selective process (Suartha, 2016). With advances in technology and transportation infrastructure, labor mobility continues to increase. Labor migration encourages growth.

In the domestic sphere, it shows that labor migration contributes to aggregate growth by improving the distribution of labor which then encourages concentration. With the occurrence of the grouping of skills and talents possessed by the workforce can create an abundance of agglomeration to other regions. Some non-economic factors that influence a person's desire to migrate are: 1) social factors including the desire of migrants to break away from the traditional constraints contained in social organizations that previously restrained them; 2) physical factors including climate influences and meteorological disasters such as floods and droughts. 3) demographic factors including a reduction in mortality rates which then accelerates the rate of growth of a population somewhere; 4) cultural factors including fostering the sustainability of large family relationships that are at the destination of migration; 5) communication factors including the quality of all means of transportation, education systems that tend to be oriented towards city life. The more advanced socioeconomic conditions of a region will create full factors such as industrial development, trade, education, housing and transportation. This condition is in demand by residents of other regions who hope to meet their needs and desires. On the other hand, each region has a push factor that causes a number of residents to migrate outside their regions.

Effect of Population Development on Economic Development in Bali Province. The results of data analysis show that population development has a positive and significant impact on economic development in Bali. This means that if the population increases, it will be able to increase the economy as well, and vice versa.

Population growth in an area on one side will constitute development capital, because there is a work force in accordance with the development of the population. However, economic development cannot be separated from the optimization of resource allocation, both physical, natural and human resources. The trigger factor for migration is very complex, especially the reasons for meeting the needs of life. Until now migrants made economic 
motives as a reason for someone to make a move. Gilbert and Gugler (1996) say the majority of the population moves because of economic reasons. Dustmann (2007) added that not only economic reasons, but also those caused by natural disasters. The economic factors in question can be in the form of employment status, level of wages, amount of income, house ownership, and ownership of agricultural land. People tend to move to areas that promise a better life (Ananta, 1985).

Likewise in Bali Province, migration rates are still relatively positive. This means that many residents migrate (risen) to Bali, or if viewed by regency/city, the destination of migration is only in Denpasar City or Badung Regency. Migrants from outside Bali generally go to Bali to work in the informal sectors, because the interest of local residents to fill the informal sector is not high.

Likewise Denpasar City and Badung Regency became the destination of risk migration because they provided many jobs and employment opportunities, especially in the tourism and government sectors. In addition, Denpasar City is also a trade center and government center, as well as the availability of various education and health facilities. So it is normal for migration to the area.

PopulationControl Efforts in Bali Province. Population control is a strategic issue that will have a major impact on development. The population is indeed the source of labor and the main economic capital of a region. But when the population cannot be controlled, it will become a burden for the government. For example, if the population of productive age is less than the population of productive age, it would certainly be a heavy burden with a high dependency rate. If the population of productive age is many, but not followed by the quality and availability of employment, then it could be a burden on the State, increasing unemployment, and prone to trigger crime.

As discussed earlier, that an increase in the population of birth factors can be controlled through a Family Planning program. Through the Family Planning program carried out by the Bali Provincial BKKBN (National Family Planning Coordinating Board) and related agencies, it is expected that the community can plan the number and time of birth, so that the population can be controlled.

Furthermore, related to the high level of migration in certain regions, it is necessary to study the causes of migration. The general population will migrate to areas that have or suspected to open many job opportunities. Migration between regencies/cities in Bali Province tends to be unbalanced. Incoming migration is dominated by Badung Regency and Denpasar City, while other areas tend to be negative. Therefore, a program for equitable development and expansion of employment is needed that is evenly distributed to all regencies/cities in Bali.

\section{CONCLUSION}

The results of data analysis and discussion show that population migration has a positive and significant effect on population development and economic development in Bali Province. Furthermore, population development also has a positive and significant impact on economic development in the Province of Bali. Population development was also proven to significantly mediate the influence of population migration on economic development in Bali Province. Efforts to control the population in Bali Province need to be done through efforts to strengthen the Family Planning program to control birth rates. In addition, it is necessary to make equitable development in various regions both in Bali and in Indonesia, so that population migration does not only focus on certain regions, including in Bali Province.

There are several things that can be suggested as a follow-up to the results of the study, namely:

- It is necessary to strengthen the population control program and coordinate arrangements between institutions that handle the central level population control (BKKBN) and regional apparatus organizations (OPD) in the regions;

- Equitable development and the distribution of the potential of the regency in the Province of Bali need to be carried out not to focus only on areas that have 
developed. Equitable infrastructure development is also believed to be able to open investment opportunities in remote areas;

- The younger generation is directed to develop entrepreneurial skills, so they can become job creators without the need to migrate to urban areas and can have a positive impact on the economic development of their regions.

\section{REFERENCES}

1. Ananta. 1985. Ten "Windu" (Eight Years Cycle) Transmigration in Indonesia 1905-1985. Jakarta: University of Indonesia.

2. Arsyad, Lincolin. 2010. Development Economy. Jakarta: Ghalia Indonesia.

3. Central Bureau of Statistics of Bali Province. 2018. Bali in Figure 2018. Denpasar: Central Bureau of Statistics of Bali Province.

4. Boediono. 2001. Development Economics. Jakarta: LPUI.

5. Dustmann, C. and Y. Weiss. 2007. Return Migration: Theory and Empirical Evidence from the UK. British Journal of Industrial Relations. Vol 45, pp 236-256.

6. Gilbert, A. and J. Gugler. 1996. Urbanization and Poverty in the Third World. (Transfer Language: Anshori and Juanda). Yogyakarta: PT Tiara Wacana Yogya.

7. Keyfitz, N. and Nitisastro, W. 1997. Indonesian Population and Development Issues. Jakarta: PT Pembangunan.

8. Mantra, I. B. 2000. Survey Research Methodology. Yogyakarta: Offset Student Library.

9. Murni, Asfia, 2006. Macroeconomics of Economic Growth and Macro Policy. Bandung: PT. Refika Aditama.

10. Suartha, N. 2016. Factors Affecting the High Growth Rate and Implementation of Population Policy in Bali Province. PIRAMIDA. Vol. XII, No.1: 1-7.

11. Sukamdi and G. Mujahid. 2015. Internal Migrations in Indonesia. UNFPA Indonesia. Monograph Series No.3.

12. Todaro, M. P. and S.C. Smith. 2003. Economic Development in the Third World. Eighth Edition. Jakarta: Erlangga. 